\title{
Yield and Quality of Winter Cereal-Legume Fodder Mixtures and their Pure Stand under Temperate Conditions of Kashmir Valley, India
}

\author{
S. Ansarul Haq", K. Joseph Korieng, T.A. Shiekh, F.A. Bahar, Khurshid A. Dar, \\ Waseem Raja, Rayees A. Wani and N.S. Khuroo
}

Dry Land Agriculture Research Station, Budgam, SKUAST-Kashmir, J\&K, India

*Corresponding author

\section{A B S T R A C T}

\begin{tabular}{|l|}
\hline K e y w o r d s \\
Avena sativa, \\
$\begin{array}{l}\text { Hordeum vulgare, } \\
\text { Lolium multiflorum, } \\
\text { Pisum sativum, Vicia } \\
\text { sativa, Mixed } \\
\text { cropping, Crude } \\
\text { protein }\end{array}$ \\
\hline Article Info \\
\hline $\begin{array}{l}\text { Accepted: } \\
\text { 28 December } 2017 \\
\text { Available Online: } \\
\text { 10 February } 2018\end{array}$ \\
\hline
\end{tabular}

\section{Introduction}

Cereals like oats, barley and ryegrass are the important rabi fodders grown under rainfed conditions of Kashmir for the sustenance of livestock. No doubt these are palatable, succulent and nutritious fodders with sufficient amount of carbohydrate but these are deficient in protein which is necessary for animal health and productivity. Literature also revealed that intake of fodder is low when fed as pure fodders either of legumes or cereals compared with their cereal legume mixtures. Oats form an excellent combination, when fed alongwith other cold seasonal legume crops like berseem, lucerne (alfalfa), senji (Indian clover), shaftal (Persian clover) and vetch (Vicia sativa). Barley too is winter hardy and potentially promising crop in the annual legume-cereal mixtures for forages and hay product (Yasar and Buyukburc, 2003). The mixed cropping of vetch with oats, barley and ryegrass may affect the growth rate of individual species in mixtures as well as 
forage yield and quality (Lithourgidis et al., 2006). Cereals can provide support for climbing vetches, improve light interception and thus facilitate mechanical harvesting. Incorporation of legume with cereal could be of paramount importance for nutritive value of forage mixture and also to subsequent soil health.

Monocultures of common vetch or cereals do not provide satisfactory results for forage production (Osman and Nersoyan, 1986). Common vetch is low-yielding, particularly in areas with low rainfall (Hadjichristodoulou, 1978) and hinders harvest because it normally lays on the soil surface (Robinson, 1969). On the other hand, small grain cereals provide high yields in terms of dry weight but they produce forage with low protein (Lawes and Jones, 1971). Forage quality of cereal hay is usually lower than that required to meet satisfactory production levels for many categories of livestock. In mixtures, companion cereals provide structural support for common vetch growth, improve light interception, and facilitate mechanical harvest, whereas common vetch in mixtures improves the quality of forage (Robinson, 1969; Thompson et al., 1992). Other benefits of mixtures include greater uptake of water and nutrients, enhanced weed suppression, and increased soil conservation (Stern, 1993; Ranells and Wagger, 1997; Anil et al., 1998; Vasilakoglou et al., 2005).Present study was undertaken to evaluate the effect of cereals and legumes a monoculture as well as in mixtures on yield and yield components of fodder in Kashmir region.

\section{Materials and Methods}

The experiment was conducted for three consecutive years during rabi 2013-14, 201415 and 2015-16 at Mountain Livestock Research Institute (MLRI), Manasbal, SKUAST-K of Kashmir Himalayas, in a randomized block design with three replications. The experiment was done under coordinated mode of All India Coordinated Research Project on Forage Crops and Utilization (AICRP-FC\&U) and the objective of this study was to evaluate fodder yield potential and quality of cereals and legumes in mono as well as in mixed cropping. The treatments consisted of five sole and six intercrops (T1 - Sole Oat,T2 - Sole Barley,T3 - Sole ryegrass,T4 - Sole Vetch, T5 - Sole Field pea,T6 - Oat+ Vetch (1:1),T7 - Oat + Field pea (1:1),T8 - Barley +Vetch (1:1),T9 Barley +Field pea (1:1),T10 -Ryegrass +Vetch (1:1) and T11- Ryegrass + Field pea (1:1).All recommended management practices were adopted for growing of crop. Nitrogen in the form of urea was applied in three split doses, half as basal and another half in two equal splits and full amount of phosphorus and potassium as per the package and practices of the crop in the forms of diammonium phosphate (DAP) and muriate of potash (MOP) as basal dose. The plant samples were taken from randomly selected $1 \mathrm{~m}^{2}$ area of each plot at different growth stages to record fodder yield and yield components. Data regarding plant height, number of leaves per plant, leaf to stem ratio, fresh weight per plant, dry weight per plant, green fodder yield and dry matter yield were recorded. Green fodder and dry fodder yields were determined by harvesting $1 \mathrm{~m}^{2}$ of each plot by hand.

The fodder yield was calculated after drying a sample of $500 \mathrm{~g}$ fodder in an oven at $78^{\circ} \mathrm{C}$ for 48 hours. For forage quality at harvest, a second set of random samples of $1 \mathrm{~kg}$ biomass from each plot was taken. Samples were dried in the oven for $72 \mathrm{~h}$ at $65{ }^{\circ} \mathrm{C}$ and prepared for chemical analysis. The samples were ground with a Wiley mill to pass a $1 \mathrm{~mm}$ screen and analyzed for quality components. Total $\mathrm{N}$ was determined using the Kjeldahl method and crude protein (CP) was calculated by multiplying the $\mathrm{N}$ content by 6.25 . 
Soil morphological, physical and chemical properties

The experimental site characteristics (Sehgal, 1994) revealed that the topography was almost flat, with slope gradient ranging from $0-1 \%$. The soil was well drained; the groundwater depth was greater than $10 \mathrm{~m}$ with no flooding and rock outcrops. The morphological characteristics (Soil Survey Staff 1999) revealed that the upper and lower horizons had 10YR hue value from 3 to 6 and chromas from 2 to 4 . The Bt horizon of the pedons contained clay cutans (Argillans); their orientation was thick and continuous. These soils are mature and were classified as Typic Hapludalfs (Soil Survey Staff 1998).

\section{Statistical analysis}

To carry out the main effects as well as the interaction effects of main treatments, analysis of variances (ANOVA) technique using factorial randomized block design (RBD) (Gomez and Gomez 1984) was performed, and the least square differences (LSD) was used for comparison between the treatments and their combinations. The statistical software packages used were MINITAB (Minitab Inc., State College, Penn.) and SPSS (SPSS Inc., Chicago, Ill.).

\section{Results and Discussion}

\section{Growth parameters}

Plant height recorded at different crop growth stages showed significant difference among the treatments (Table 1). In pure stand, maximum plant height $(120.52 \mathrm{~cm})$ was attained by oats crop followed by Barley $(92.50 \mathrm{~cm})$, rye grass $(76.25 \mathrm{~cm})$ and lowest by Field pea $(67.35 \mathrm{~cm})$. In mixtures, maximum plant height $(139.30 \mathrm{~cm})$ was obtained by oats + vetch mixture followed by oats + field pea mixture $(118.60 \mathrm{~cm})$ and barley + vetch $(98.30 \mathrm{~cm})$. The results revealed that plant height in mixture stand is mainly influenced by pure stand of the respective cereal crops. The mixtures of oats + vetch, barley + vetch and rye grass + vetch crops obtained 15.58, 6.27 and 13.24 percent more plant height than their respective cereal counterparts which could be the result of efficient utilization of natural resources and minimum competition between the plants of different species. These results differ with the findings of Turemen et al., and Canan and Orak who reported the highest plant height in pure stand.

Leaf stem ratio represents the leaf weight divided by stem weight. In pure stand, mean maximum leaf stem ratio was recorded in rye grass (1.80) followed by vetch (0.70) and pea (0.94) (Table 1). Leaf stem ratio in crops decreased with the advancement of crop growth stage and increase in stem thickness. In mixtures, maximum leaf stem ratio was noted in rye grass + vetch (1.62) followed by rye grass + pea (1.38) mixture. The higher leaf stem ratio of rye grass + vetch mixture is the result of greater leaf weight and area in rye grass crop.

\section{Yield parameters}

Significant differences were also observed in green fodder yield recorded at different crop growth stages. In pure stand, there is no significant difference among the treatment means at early growth stages but later in the season, oats crop produced higher green fodder yield than all other sole crops in comparison. These results are similar to those of Canan and Orak who recorded higher herbage yield in oats and lower in field pea in pure stands. In green fodder yield recorded from pure stands of crops at different crop growth stages, oats crop (359.20 q/ha) ranked first followed by barley (271.35 q/ha) and rye grass $(235.30 \mathrm{q} / \mathrm{ha})$. The overall growth rate in 
all crops remain slower during December and February while it was faster from March to May with increased temperature and availability of moisture due to occurrence of rainfall during March. In mixtures the highest green fodder yield $(398.60 \mathrm{q} / \mathrm{ha})$ was obtained in oats + vetch mixture followed by oat + field pea (312.30 q/ha). Canan and Orak also reported that mixtures were more productive than pure vetch sowing. They also quoted in another place that maximum herbage yield was obtained from mixture of vetch $(25 \%)$ and oats $(75 \%)$ and minimum from pure stand of vetch.

Table.1 Effect on growth and yield of cereals with different legume intercropping

\begin{tabular}{|l|l|c|c|c|c|}
\hline $\begin{array}{l}\text { Treatment } \\
\text { code }\end{array}$ & Treatment & $\begin{array}{l}\text { Plant height } \\
(\mathbf{c m})\end{array}$ & $\begin{array}{l}\text { L:S } \\
\text { ratio }\end{array}$ & $\begin{array}{l}\text { Fresh weight } \\
\text { (q/ha) }\end{array}$ & $\begin{array}{l}\text { Dry weight } \\
\text { (q/ha) }\end{array}$ \\
\hline T1 & Sole Oat & 120.52 & 0.46 & 359.20 & 75.39 \\
\hline T2 & Sole Barley & 92.50 & 0.44 & 271.35 & 58.78 \\
\hline T3 & Sole Ryegrass & 76.25 & 1.80 & 235.30 & 54.04 \\
\hline T4 & Sole Vetch & 76.20 & 0.70 & 210.00 & 43.80 \\
\hline T5 & Sole Field pea & 67.35 & 0.52 & 195.80 & 48.75 \\
\hline T6 & Oat + Vetch & 139.30 & 0.64 & 398.60 & 88.04 \\
\hline T7 & Oat + Field pea & 118.60 & 0.58 & 312.30 & 64.40 \\
\hline T8 & Barley + Vetch & 98.30 & 0.48 & 298.00 & 67.00 \\
\hline T9 & Barley + Field pea & 88.50 & 0.44 & 240.00 & 55.20 \\
\hline T10 & Ryegrass + Vetch & 86.35 & 1.62 & 245.00 & 54.15 \\
\hline T11 & Ryegrass + Field pea & 80.28 & 1.38 & 200.00 & 46.25 \\
\hline SEm \pm & & $\mathbf{2 . 2 5}$ & $\mathbf{0 . 0 1}$ & $\mathbf{3 . 7 1}$ & $\mathbf{1 . 2 2}$ \\
\hline CD at 5\% & & $\mathbf{6 . 5 8}$ & $\mathbf{0 . 0 4}$ & $\mathbf{1 0 . 8 5}$ & $\mathbf{3 . 5 8}$ \\
\hline
\end{tabular}

Table.2 Effect of quality parameters with different cereals and legume intercropping

\begin{tabular}{|l|l|l|l|l|l|}
$\begin{array}{l}\text { Treatmen } \\
\text { t code }\end{array}$ & Treatment & $\begin{array}{l}\text { Crude } \\
\text { protein } \\
\text { content }(\%)\end{array}$ & $\begin{array}{l}\text { Crude } \\
\text { protein yield } \\
\text { (q/ha) }\end{array}$ & $\begin{array}{l}\text { Nitrogen } \\
\text { content (\%) }\end{array}$ & $\begin{array}{l}\text { Nitrogen } \\
\text { uptake } \\
\text { (kg/ha) }\end{array}$ \\
\hline T1 & Sole Oat & 7.9 & 5.89 & 1.26 & 94.26 \\
\hline T2 & Sole Barley & 11.23 & 7.02 & 1.8 & 112.28 \\
\hline T3 & Sole Ryegrass & 6.54 & 3.61 & 1.05 & 57.72 \\
\hline T4 & Sole Vetch & 20.89 & 9.53 & 3.34 & 152.38 \\
\hline T5 & Sole Field pea & 19.3 & 9.96 & 3.09 & 159.3 \\
\hline T6 & Oat + Vetch & 12.85 & 11.31 & 2.05 & 180.48 \\
\hline T7 & Oat + Field pea & 11.6 & 7.02 & 1.85 & 112.22 \\
\hline T8 & Barley + Vetch & 14.98 & 10.03 & 2.4 & 160.80 \\
\hline T9 & Barley + Field pea & 13.02 & 6.95 & 2.08 & 111.19 \\
\hline T10 & Ryegrass + Vetch & 11.12 & 6.02 & 1.78 & 85.02 \\
\hline T11 & Ryegrass + Field pea & 9.8 & 4.43 & 1.57 & 70.84 \\
\hline SEm \pm & & - & $\mathbf{0 . 2 4}$ & $\mathbf{0 . 1 9}$ & $\mathbf{3 . 0 2}$ \\
\hline CD at 5\% & & - & $\mathbf{0 . 7 2}$ & $\mathbf{0 . 5 3}$ & $\mathbf{8 . 7 6}$ \\
\hline
\end{tabular}


The data (Table 1) indicated a dry matter yield trend similar to green fodder yield. In pure stands, maximum dry matter yield was obtained by oats crop (75.39 q/ha) followed by barley and rye grass. In mixtures, oats + vetch ranked first $(88.04 \mathrm{q} / \mathrm{ha})$ followed by barley + vetch $(67.0 \mathrm{q} / \mathrm{ha})$ and oat + field pea (64.40 q/ha). The present results also revealed that mixtures gave higher yields than the pure sowings.

\section{Quality parameters}

Both crude protein and nitrogen content showed significant differences among the treatments (Table 2). In pure stand, maximum crude protein content $(20.89 \%)$ and nitrogen content $(3.34 \%)$ was attained by sole vetch and the minimum in rye grass. In mixtures, barley + vetch ranked first in both crude protein content (14.98\%) and nitrogen content $(2.40 \%)$ as compared to other mixtures and the minimum was found in rye grass + field pea.

The study concludes that the highest green fodder, dry matter and crude protein yields were obtained from oats-vetch mixture under temperate conditions of Kashmir valley. In pure stands maximum green fodder yield was recorded in oats crop followed by barley, rye grass and vetch.

\section{References}

Anil, L., Park, J., Phipps, R.H., Miller, F.A., 1998. Temperate intercropping of cereals for forage: a review of the potential for growth and utilization with particular reference to the UK. Grass Forage Sci. 53, 301-317.

Canan, T. and A. Orak. 2002. Yield and yield components of some important common vetch (Vicia sativa L.) genotypes. Bulgarian J. Agric. Sci., National
Centre for Agrarian Sciences. 15: 215218.

Gomez, K. A., and A. A. Gomez. 1984. Statistical procedures for agricultural research. New York: John Wiley.

Hadjichristodoulou, A., 1978. Genotype, environment and rainfall effects on common vetch varieties in a semiarid region. Exp. Agric. 14, 81-87.

Lawes, D.A., Jones, D.I.H., 1971. Yield, nutritive value and ensiling characteristics of whole-crop spring cereals. J. Agric. Sci. 76, 479-485.

Lithourgidis, A. S., I. B. Vasilakoglou, K. V. Dhima, C. A. Dordas and M.D. Yiakoulaki. 2006. Forage yield and quality of common vetch mixtures with oat and triticale in two seeding ratios. Field Crops Research. 99:106-113.

Osman, A.E., Nersoyan, N., 1986. Effect of the proportion of species on the yield and quality of forage mixtures, and on the yield of barley in the following year. Exp. Agric. 22, 345-351.

Ranells, N.N., Wagger, M.G., 1997. Grasslegume bicultures as winter annual cover crops. Agron. J. 89, 659-665.

Robinson, R.C., 1969. Annual legume: cereal mixtures for forage and seed. Agron. J. 61, 759-761.

Sehgal, J. L. 1994. Soil resource mapping of different states of India (Soil Bulletin No. 23). Nagpur: National Bureau of Soil Science and Land Use Planning.

Soil Survey Staff. 1998. Keys to soil taxonomy. Available at http//www. statlab.iastate.edu/soils/keytax/.

Soil Survey Staff. 1999. Soil taxonomy: A basic system of soil classification for making and interpreting soil Surveys (U.S. Department of Agricultural Handbook No. 436), 2nd ed. Washington, D.C.: U.S. Government Printing Office.

Stern, W.R., 1993. Nitrogen fixation and 
transfer in intercrop systems. Field Crops Res. 34, 335-356.

Thompson, D.J., Stout, D.G., Moore, T., 1992. Forage production by four annual cropping sequences emphasizing barley irrigation in southern interior British Columbia. Can. J. Plant Sci. 72, 181185.

Turemen, T., T. Saglamtimur, V. Tansi and H. Baytekin. 1990. Performance of annual ryegrass and common vetch in association under different ratios. C. Uni. J. Fac. Agric., 5(1): 69-78.
Vasilakoglou, I.B., Lithourgidis, A.S., Dhima, K.V., 2005. Assessing common vetch: cereal intercrops for suppression of wild oat. In: Proceedings of the 13th International Symposium, Session S5, European Weed Research Society, Bari, Italy.

Yasar, K. and U. Buyukburc. 2003. Effect of seed rates on forages production, seed yield and hay quality of annual legumebarley mixtures. Turk. J. Agric. For. 27: $169-174$.

\section{How to cite this article:}

Ansarul Haq, S., K. Joseph Korieng, T.A. Shiekh, F.A. Bahar, Khurshid A. Dar, Waseem Raja, Rayees A. Wani and Khuroo, N.S. 2018. Yield and Quality of Winter Cereal-Legume Fodder Mixtures and their Pure Stand under Temperate Conditions of Kashmir Valley. Int.J.Curr.Microbiol.App.Sci. 7(02): 3626-3631. doi: https://doi.org/10.20546/ijcmas.2018.702.431 